\title{
Community Perspective of Maternal Mortality: Experience from Konduga Local Government Area, Borno State, Nigeria
}

\author{
M. B. Kawuwa, A. G. Mairiga and H. A. Usman \\ Department of Obstetrics and Gynaecology, University of Maiduguri Teaching Hospital, Maiduguri, Borno \\ State, Nigeria \\ Reprint requests to: Dr Mohammed Bello Kawuwa, Department of Obstetrics and Gynaecology, University of \\ Maiduguri Teaching Hospital, P. M. B. 1414 Maiduguri, Borno State, Nigeria \\ E-mail: bellokawuwa@yahoo.com
}

\begin{abstract}
Background/objective: High maternal mortality in Nigeria in particular and Sub-Saharan Africa in general has remained one of the key indicators of our poor health care services, infrastructural facilities and negative socio-cultural attitudes to healthy living. The objective is to identify barriers to prompt and effective treatment of obstetric complications leading to maternal mortality in order to develop appropriate strategies to address them at the community level.

Method: The study took place between $10^{\text {th }}$ October and $10^{\text {th }}$ December 2003 . An in-depth interview guide developed by the network for the prevention of maternal mortality (NPMM), which contains mainly open ended questions, modified to suit our socio-cultural setting was used.

Results: There was a good understanding among the people of the area that women are dying during pregnancy, labour and puerperium. 28(93.3\%) of the respondents recognized some obstetric complications. The main obstacles to accessing the hospital for emergency obstetric care were lack of money and transportation difficulties. Equipping the health facilities, employment of qualified staff, community supported emergency funds for obstetric emergency and the provision of reliable, effective and affordable transport are identified as necessary measures to prevent maternal mortality. The Local Government Areas and community leaders are to champion the cause for the provision of these facilities in their localities.

Conclusion: There is a good understanding of obstetric complications in the community leading to maternal death. The main reasons for delay in seeking care are ignorance, poverty, lack of transportation and distance. Community enlightenment, health education, training of TBAs, poverty reduction and effective, affordable and reliable transportation are means of obviating delays in the decision and transportation leading to maternal mortality. Upgrading and re-equipping of health facilities to provide emergency obstetric care services are mandatory. Community participation in the safe motherhood drive can be ensured using the traditional rulers, religious leaders and the Local Government Authority.
\end{abstract}

Keywords: Maternal mortality, barriers to care, community perspective

\section{Résumé}

Introduction/objectif: Le taux élevé de la mortalité maternelle au Nigéria en particulier et dans l'Afrique du sous Sahara en général demeure toujours un des indicateurs clés de notre services des soins médicaux pauvres aménagement infrastructural et comportement socio-culturel négatif face à une vie saine. L'objet est d'identifier des obstacles aux traitement efficace et rapide des complications obstétriques menant à la mortalité maternelle afin de préparer des stratégies adéquates pour resoudre ces problèmes au niveau communautaire.

Méthodes: L'étude a eu lieu entre $1^{\mathrm{e}} 10$ octobre au 10 décembre 2003 . Un guide d'un entretien en profondeur préparé par la prévention de la mortalité marternelle de reseau (PMMR) se compose principalement des questions libre, modifié d'après notre milieu socio-culturel était utilisé.

Résultats: Il y avait un très bonne entente entre les gens de ce milieu que des femmes sont mort pendant grossesse, accouchement et puerpérium. 28(93,3\% des sondés reconnaissent quelques complications obstétriques. L'obstacle le plus majeur pour aller à l'hôpital pour des soins obstétriques d'urgence était pénurie d'argent, et problèmes du transport, des équipements dans l'aménagement de santé, le fait d'embaucher des employés qualifiés, ressources d'urgence pour aider la communauté pour des urgences obstétriques et la prestation du transport fiable, efficace et abordable sont notés comme les grands 
moyens nécéssaires afin d'éviter la mortalité maternelle. Les zones d'administration départementale et des chefs de la communauté sont responsable pour soutenir la cause de la prestation de ces resources dans leur régions.

Conclusion: C'est sûr et certain qu'il y a des complication obstétriques dans la communauté qui conduissent aux morts marternelles. Des raisons principales qui empèche le fait d'aller bien vite recevoir des soins sont : ignorance, la pauvreté, manque du transport et la distance, éclairecissement communautaire, enseignement sanitaire, formation de TBAs, diminution efficace du niveau de la pauvreté, moyen de transport fiable et abordable sont des moyens menant à une décision tardive menant à la mortalité maternelle. C'est obligatoire d'améliorer les équipements dans les aménagement de la santé pour pouvoir fournir des services des soins d'obstétriques d'urgence. Participation communautaire dans le mouvement de la maternité fiable peut enter en vigeur à travers la participation des chefs et rois traditionnel, chef réligieux et les dirigeants de l'administration départementale.

Mots-clés: Mortalité maternnelle, obstacles aux soins, perspectif communautaire

\section{Introduction}

Maternal mortality is defined as 'the death of a woman while pregnant or within forty two days of the termination of pregnancy, irrespective of the duration and site of the pregnancy from any course related to or aggravated by pregnancy or its management, but not from accidental or incidental causes'. ${ }^{1}$

Some $80 \%$ of all maternal deaths worldwide are the direct result of complications arising during pregnancy, delivery, or the first six weeks after birth. The five main causes of maternal mortality are haemorrhage, responsible for about a quarter of all maternal deaths, hypertension / eclampsia, infections, unsafe abortion and obstructed labour. 2, 3 The remaining $20 \%$ of maternal deaths are the result of pre-existing health conditions that are exacerbated by pregnancy or its management. Other important indirect causes of death include malaria, hepatitis, heart disease, and increasingly in some settings, HIV/AIDS. ${ }^{2,4-6}$

Maternal mortality is a public health hazard and it is a measure of standard of health care system of a given society. ${ }^{7,8}$ Maternal mortality represents one of the starkest and most unacceptable gaps between the developed and developing countries, with $98 \%$ of all maternal deaths occurring in developing countries. In developed countries, there are approximately 27 maternal deaths per 100,000 live births each year. In developing countries the average is 18 times higher at 480 deaths per 100,000 live births. ${ }^{2}$ In some developing countries, one woman in 10 dies from a pregnancy related cause. In industrialized countries, the chances average one in 4,000. ${ }^{2,9,10}$ Overall each year close to 600,000 women, more than one every minute die from complications related to pregnancy and childbirth. ${ }^{9,10}$

Over $90 \%$ of maternal deaths in developing countries are preventable. There is no single pathway to achieving this goal; the approach must be multidimensional. Poor infrastructural development in many developing countries, especially sub - Saharan Africa, impact adversely on maternal mortality. The situation is worse in rural areas. Bad roads render some areas inaccessible throughout the year or during the rainy season. All season motorable roads are mostly a luxury. Transportation is another problem even where a motorable road exists. Public transportation is sometimes inadequate. Commercial vehicle drivers may be reluctant to carry a woman who has haemorrhage to avoid soiling their vehicles. Private vehicle owners in the village may be few or unwilling to put their vehicles on the road for emergencies especially at night for security reasons. ${ }^{11}$

Over the decades reduction in maternal mortality merely received national attention in the developed countries and little or no attention in the developing world. Global attention was only drawn to the high maternal mortality in developing countries in 1987 when the first international conference on safe motherhood was organized in Nairobi, Kenya by World Health Organization (WHO), United Nations Fund for Population Activities (UNFPA), World Bank, and other stakeholders. Despite concerted efforts by these International Organizations, Governments and NGOs, maternal mortality figures were found to be rising in most developing countries, a typical example being Nigeria where the most recent reports show a rising and unacceptably high maternal mortality figures. $12-16$ Borno State where this study was conducted belongs to the region (Northeastern) with worse maternal mortality figures in Nigeria, over 1500 per 100,000 live births. ${ }^{17-20}$

This study went to the grass roots to determine the factors that contribute to maternal death and disabilities. The objectives were: to identify barriers to prompt and effective treatment of obstetric complications in order to develop appropriate strategies to address these problems. By: 1) Obtaining information on community's understanding of obstetric complications, 2) Exploring the factors affecting the decision-making process concerning obstetric complications, and 3) Obtaining community input concerning potential strategies for improving the utilization of emergency obstetric care.

\section{Materials and Methods}

\section{Setting}

Konduga Local Government Area of Borno State has an area of about 6,000 square kilometers with a population of 375,000 . Out of this 206,250 (55\%) are women. Women aged 15-49 years (reproductive age) 
are 93,750 (25\% of the total population) or $45.5 \%$ of the women population. The ethnic groups in the local government are: Kanuri, Shuwa Arab, Marghi, Mulgwai, Wula, Gamargu, Fulani and Hausa. The main occupation of the people is subsistence farming combined with livestock rearing, fishing and trading. The road network in the Local Government may be over $300 \mathrm{~km}$ mostly (over 90\%) untarred bush roads and footpaths with a substantial part of the villages living behind a river, which keeps them away from the local government headquarters. The principal means of transport from the local government headquarters to the villages are: four wheel drive motor vehicles, pick up vans with high suspension, cattle and horse driven carts and manual push - push carts. Those living behind the rivers use canoes to cross to the local government headquarters. The terrain becomes difficult during the rainy season.

The local government has one general hospital at the local government headquarters, which is being manned by the Borno State Hospitals Management Board. The local government has a total of 28 health centers and 18 dispensaries. There is a maternity center located in the heart of the local government headquarters (Konduga). The local government has one medical doctor, six nurses/midwives, fifty eight traditional birth attendants (TBAs) and 40 community health extension workers (CHEWs). The local government has one ambulance. There is no blood transfusion center. The family health international and federation of Muslim women associations of Nigeria (IFH/FOMWAN) train midwives in the local government on manual vacuum aspiration/post abortion care/sexually transmitted infections (MVA/PAC/STIs) and HIV (Source: Konduga Local Government Health Statistics Office).

\section{Method}

The study took place between October and December 2003. An in-depth interview guide developed by the Network for the prevention of maternal mortality (NPMM), which contained mainly open ended questions, modified to suit our socio-cultural setting were used. Interviews were conducted on representatives of recognized social/interest groups in the community including traditional leaders, religious leaders, local government administrators, teachers, civil servants, members of the national union of road transport workers (NURTW), women community leaders and women non-governmental organizations and staff of the local government primary health care department. The interview was conducted in Hausa and English languages. There was no need for interpreters. The members of NPMM Borno State chapter conducted the interview. They comprise doctors, nurses, midwives and social workers.

The questions asked were directed at how to recognize obstetric complications, obtaining care for obstetric complications, decision-making concerning obstetric care and suggestions for addressing barriers to care. All the interviews took place in the offices or residences of the respondents and lasted about 45 minutes. Notes were taken by one of the interviewers always; sometimes the proceedings were audio taped. Audio taped interviews were immediately transcribed to obtain full details of the interview in addition to the notes taken. Thirty people were interviewed (minimum of 3 from each of the groups).

\section{Results}

In general there was a fair understanding among the people of the area that women are dying during pregnancy, labour and puerperium. There was a poor knowledge of pregnancy complications among the religious leaders in the area, which was manifested from both the Muslim and Christian scholars. But all others interviewed identified at least 3 obstetric complications (Table 1). All believe that obstetric complications are dangerous but could not determine when it is serious, as all indicated terminal stage of complications as a time of seriousness such as fitting in eclampsia, shock in bleeding or vesico-vaginal fistula in obstruction. Twenty eight (93.3\%) respondents recognized some obstetric complications while $2(6.7 \%)$ were not sure if there is any complication associated with pregnancy, labour or puerperium.

All the respondents indicated that if there are any of the mentioned obstetric complications, the woman is taken to the hospital and it is the responsibility of the husband and his relations to assist the woman. Other people who render assistance in one form or the other include TBAs, CHEWs, friends and the local government authority (Table 1).

The main problems considered in deciding to take a woman to the Hospital were lack of money and transport (93.3\%). Another factor considered in seeking care was the community's impression of the health facility's capability to handle their problem. Buses/cars pick up vans, motorcycles and bicycles usually transport patients with obstetric complications. Push-push carts or ox driven carts were some time employed especially in bad terrain in the remote areas during the rainy season. The husband, a relation or the local government council provides money. Sometimes a patient has to sell her farm produce or seek loan to finance transportation and medical expenses. Cost of care was put at 500010,000 Naira. The relations usually settle the bill, where they cannot, the local government council pays.

All the respondents believe that much needs to be done at the community level, and that government needs to have more commitment to the lives of women with obstetric complications. Suggestions were to equip existing hospitals (100\%), employ more qualified staff $(100 \%)$ to handle obstetric emergencies, community participation in form of assistance, donations to needy emergency obstetric cases and, provision of reliable, effective and affordable transport for emergency cases (56.7\%).

The respondents suggested that traditional leaders, local government council and religious leaders should work actively to address the problems militating against safe motherhood. 
Table 1: Recognizing obstetric complications, barriers to care and suggestions as perceived by 30 respondents

\begin{tabular}{|c|c|c|}
\hline Question & Response & No $(\%)$ \\
\hline \multirow[t]{9}{*}{ Recognizing obstetric complications } & Obstetric complications & \\
\hline & Bleeding & $26(86.7)$ \\
\hline & Eclampsia/high blood pressure & $17(56.7)$ \\
\hline & Vesico-vaginal fistula & $14(46.7)$ \\
\hline & Prolonged labour & $11(36.7)$ \\
\hline & Retained placenta & $7(23.3)$ \\
\hline & Anaemia & $6(20.0)$ \\
\hline & Malpresentation & $4(13.3)$ \\
\hline & Stillbirth & $4(13.3)$ \\
\hline \multirow{9}{*}{$\begin{array}{l}\text { Responsibility of obtaining care for obstetric } \\
\text { complications }\end{array}$} & Person responsible & \\
\hline & Husband & $30(100)$ \\
\hline & Relations & $26(86.7)$ \\
\hline & Local government & $18(60.0)$ \\
\hline & TBAs & $10(33.3)$ \\
\hline & Chews & $4(13.3)$ \\
\hline & Friends & $4(13.3)$ \\
\hline & Red cross & $2(6.7)$ \\
\hline & Eldest son & $2(6.7)$ \\
\hline \multirow[t]{8}{*}{ Considerations in decision to seek care } & Problem considered & \\
\hline & Money/finance & $30(100)$ \\
\hline & Transport & $30(100)$ \\
\hline & Distance & $28(93.3)$ \\
\hline & Traditional /spiritual therapy & $9(30.0)$ \\
\hline & Poor facility in the hospital & $2(6.7)$ \\
\hline & Fear of transfusion & $2(6.7)$ \\
\hline & Attitude of the hospital staff & $1(3.3)$ \\
\hline \multirow[t]{6}{*}{ People's perception of the health facility (hospital) } & Perceptions (observations) & \\
\hline & Poorly equipped & $24(80.0)$ \\
\hline & Staff-friendly & $16(53.3)$ \\
\hline & Staff-unfriendly & $8(26.7)$ \\
\hline & Lack of enough qualified staff & $8(26.7)$ \\
\hline & Lack of drugs & $7(23.3)$ \\
\hline \multirow[t]{10}{*}{ Suggestions for improving access to care } & Suggestions & \\
\hline & Equip existing hospitals & $30(100)$ \\
\hline & Employ more qualified staff & $30(100)$ \\
\hline & Community participation: & $17(56.7)$ \\
\hline & Assistance /donations & \\
\hline & Enlightenment & \\
\hline & Transportation & \\
\hline & Purchase of ambulance & $11(36.7)$ \\
\hline & Building of more clinics & $5(16.7)$ \\
\hline & Supply more drugs & $5(16.7)$ \\
\hline \multirow{5}{*}{$\begin{array}{l}\text { Whom in the community should actively work to address } \\
\text { these problems }\end{array}$} & Person to work & \\
\hline & Traditional rulers & $26(86.7)$ \\
\hline & Local government council & $17(56.7)$ \\
\hline & Religious leaders & $10(33.3)$ \\
\hline & NURTW & $2(6.7)$ \\
\hline
\end{tabular}

NURTW: National union of road transport workers; TBAs: Traditional birth attendants

\section{Discussion}

This study has brought to the fore that the people in the community have good knowledge that their women are dying from pregnancy complications. They are equally aware of the leading causes of death in this respect. However, they only appreciated the terminal stage of complications, as the time when the situation is said to be serious. This finding agrees with a study in some selected states of the Nigerian federation. ${ }^{18}$ The inability of the people to appreciate early warning signs in obstetric complications might be a factor in delay in deciding to seek for care. Therefore in our view a mass community health education programme, highlighting the early warning signs of pregnancy complication is going to be 
indispensable in the short-term measure to reduce maternal mortality in our environment.

The respondents are of the opinion that the husband is responsible for obtaining care for his wife when she develops obstetric complications. This is followed by the relations of the husband or the woman's relations in the absence of the husband including the first son. To some extend the TBAs and CHEWs are also recognized in this decision to seek care. This finding has brought to the fore the fact that any programme in this locality aimed at addressing the issue of maternal mortality must target the men folk for it to be successful. For their sensitization, mobilization and improved awareness would equally go a long way in reducing the time lag in deciding to seek care when obstetric complications arise, and therefore avoiding fatal outcomes from such situations.

Surprisingly the local government was mentioned on this issue by $60 \%$ of the respondents as a responsible agency in the decision to seek care. This we discovered was because of the transportation and financial support the local government gives to poor patients who are sick and need to be conveyed to the hospital for appropriate treatment. This is a commendable effort on the part of the authorities. But better still the local government can initiate and support a medical emergency revolving fund to be managed directly by the communities at the ward and village levels especially for emergency obstetric care, this would be life saving.

With about $33.3 \%$ and $13.3 \%$ of the respondents recognizing the importance of the TBAs and CHEWs respectively, in the responsibility of obtaining care for the patients with obstetric complications in the community, it becomes important that in our safe motherhood drive in the short term we need to incorporate them and other health workers. The TBAs need to be trained and their knowledge and skill upgraded and made to work in cooperation with skilled midwifery attendants at the health facility. Once their income is protected, the TBAs can be key partners for increasing the number of birth at which a skilled attendant is present. In practical terms TBAs can help skilled attendants by encouraging women to attend for essential pre- and postnatal care. They are also in ideal position to work with families and communities, providing education on important messages for a healthy pregnancy and a safe birth. The TBAs were used in this way as an important link in the safe motherhood initiative in Malaysia. ${ }^{21}$

The significant factors considered in the decision to seek care apart from the earlier advanced reasons are financial considerations and means of transport $100 \%$ each and distance $93.3 \%$ of respondents. Not surprisingly these were the same factors responsible for type I and type II delays out of the three levels of delay that contribute to maternal mortality defined by Thaddeus and Maine in 1994. ${ }^{22}$ Other studies have identified these factors as causing delay in accessing health facility and therefore leading to avoidable obstetric death. ${ }^{23-25}$
Following health education to identify early symptoms and signs of danger, the need to have a community based revolving loan scheme for obstetric emergencies and standby community supported transport for obstetric emergencies becomes one of the options available to curtail maternal death in this type of community. The alternative of waving off payment for emergency obstetric care is another short-term alternative. The long-term measures would include pragmatic poverty alleviation scheme, mass education (especially girl child education), and general infrastructural development and social services including good road networks and functioning emergency obstetric care facilities within a reasonably acceptable distance. The other significant factor considered is traditional / spiritual therapy where up to $30 \%$ of respondents make it an important consideration to seek care, this is thus to serve as an alternative to orthodox care. This need to be discouraged by the religious and traditional leaders, least such treatment centers / houses become another death trap for the helpless women as is currently happening in Southern Nigeria. ${ }^{26}$ The study has shown that the community is fully aware that hospitals are poorly equipped, lack qualified personnel, drugs and supplies. This needs to be addressed as a matter of urgency by the responsible government agencies. There is also the need for an attitudinal change among health workers, to be patients friendly and more caring. This would encourage the locals to feel free to patronize our health facilities whenever the need arises without fear of harassment and humiliation.

Stakeholders in safe motherhood drive need to work with traditional rulers, religious leaders, members of the NURTW and the local government authority if a major headway is to be made in this noble drive.

There is a fairly good understanding of obstetric complications that lead to maternal death, in the community. The main reasons for delay in seeking care are ignorance, poverty, lack of transportation and distance.

Community enlightenment, health education, training of TBAs, poverty reduction and effective, affordable as well as reliable transportation are means of avoiding delays that lead to maternal mortality. Community-supported revolving fund and transport for emergency obstetric care would be life saving in the short-term. Upgrading and re-equipping of health facilities to provide emergency obstetric care services are mandatory.

\section{Acknowledgements}

Our sincere gratitude goes to all members of network for the prevention of maternal mortality, Borno State, Honorable Commissioner for Health, Borno State (Alhaji Kaka Mallam Yale), the key administrators of Konduga Local Government Council, Borno State, and all those who consented to participate in this study. The study was supported by a grant from the national headquarters of Nigerian network for the prevention of maternal mortality. 


\section{References}

1. International classification of diseases (ICD). $10^{\text {th }}$ Revision, WHO, Geneva, 1992;1238

2. United Nations, World Health Organization and World Bank partner to combat maternal mortality. The World Bank Group, News Release No. $2000 / 080 / \mathrm{S}$

3. Coverage of maternal care: a listing of available information. WHO, Geneva, 1997

4. McIntyre J, Gray G. What can we do to reduce mother-to-child transmission of HIV? BMJ 2002; 324:218-221

5. Muula AS, Phiri A. Did maternal mortality ratio increase in Malawi between 1992-1998? Review of demographic and health surveys and other data sources. Trop Doct 2003; 33: 182-185

6. Bicego G, Boerma JT, Ronsmans C. The effect of AIDS on maternal mortality in Malawi and Zimbabwe. AIDS 2002; 16: 1078-1081

7. Gibbs N. Confidential enquiry into maternal death. Br J Obstet Gynaecol 1990; 97: 97-99

8. Hogberg U. Maternal mortality: a worldwide problem. Int J Gynecol Obstet 1985; 23: 463-470

9. Global estimates of maternal mortality for 1995: result of an in-depth review, analysis and estimation strategy.

http://www.who.int/reproductivehealth/p/statement-on-maternal-mortalityestimates.en.html

10. Revised 1990 estimate of maternal mortality: a new approach by WHO and UNICEF. WHO, Geneva, 1996

11. Chukudebelu WO. Preventing maternal mortality in developing countries. In: Okonofua F, Odunsi K (eds). Contemporary obstetrics and gynaecology for developing countries. Women's Health and Action Research Centre, Benin City, 2003; 644-657

12. Agboghoroma OC, Emuveyan EE. Maternal mortality in Lagos, Nigeria: a ten-year review (1986 - 1995). Nigerian Quarterly Journal of Hospital Medicine 1997; 7: 230-233

13. Olatunji AO, Sule O. Maternal mortality at Sagamu, Nigeria. A ten-year review (1988-1997). Niger Postgrad Med J 2001; 8: 12-15
14. Aboyeji AP. Trends in Maternal mortality in Ilorin, Nigeria. J Obstet Gynecol 1998; 15: 15-20

15. Okaro JM, Umezulike AC, Onah HE, Chukwuali LI, Ezeugwu OF, Nweke PC. Maternal mortality at the University of Nigeria Teaching Hospital, Enugu, before and after Kenya. Afr J Reprod Hlth 2001; 5:90-97

16. Osuigwe SA, John CT. A ten-year review of maternal mortality at Port Harcourt, Nigeria. Niger J Clin Pract 2000; 3:80-84

17. National study on essential obstetric care facilities in Nigeria. Federal Ministry of Health, Abuja, 2003

18. Situation analysis on safe motherhood training needs in six states of Nigeria. Nigeria Partnership for Safe motherhood. Women's Health and Action Research Centre, Benin City, 2003

19. Nigeria demographic health survey 1999. National Population Commission, Abuja, 2000

20. Mairiga AG. Reproductive health in Borno State: a challenge to safe motherhood programming. Nigeria Partnership for Safe Motherhood, Newsletter 2004; 1:1

21. Skilled attendants: TBAs an important link in the chain. Safe Motherhood Newsletter 2002; 29:5

22. Thaddeus S, Maine D. Too far to walk: maternal mortality in context. Soc Sci Med 1994; 38: 1091-1110

23. De Muylder X. Maternal mortality audit in a Zimbabwean province. Arch Gynecol Obstet 1990; 247:131-138

24. Mtimavalye LA, Justesen A, Ngwalle E. Survey on institutional maternal deaths in four regions of Tanzania, July 1983-December 1984. Preliminary report: interregional meeting on the prevention of maternal mortality, Geneva, 1985. Popline Document Number 269329

25. Fawcus S, Mbizvo M, Lindmark G, Nystrom LA. Community- based investigation of avoidable factors for maternal mortality in Zimbabwe. Studies in Family Planning 1996; 27:319-327

26. Udoma EJ, Asuquo EE, Ekott M I. Maternal mortality from obstructed labour in south-eastern Nigeria: the role of spiritual churches. Int $\mathrm{J}$ Gynecol Obstet 1999; 67: 103-105 